\title{
COST-EFFECTIVE PERSONAL RADIATION DOSIMETRY
}

\author{
O. Korostynska, K. Arshak, and J. Harris \\ Microelectronics and Semiconductor Research Centre, ECE Dept., University of Limerick, Limerick, Ireland \\ E-mail: khalil.arshak@ul.ie
}

Received 2 September 2008; revised 4 April 2009; accepted 18 June 2009

\begin{abstract}
Deep understanding of physical properties of the materials under the influence of radiation exposure is vital for the effective design of dosimeter devices. Detection of radiation is based on the fact that both the electrical and the optical properties of the materials undergo changes upon the exposure to ionizing radiation. It is believed that radiation causes structural defects (called colour centres or oxygen vacancies in oxides) leading to change in their density on the exposure to radiation. Thin film technology is considered as cost-effective alternative for a broad range of sensors. However, it is especially attractive for metal oxide films with melting point below $2000^{\circ} \mathrm{C}$, as a wide range of films with mixed composition can be produced. The influence of radiation depends on both the dose and the parameters of the films including their thickness: the degradation is more severe for the higher dose and the thinner films. This paper reports on gamma radiation sensing properties of thermally evaporated $\mathrm{NbO}_{2}$ thin films. These films were deposited at different deposition rate and pressure. It was experimentally confirmed that the manufacturing parameters of the films affected their gamma radiation sensitivity.
\end{abstract}

Keywords: gamma radiation, thin film, $\mathrm{NbO}_{2}$, real-time dose monitoring, electrical and optical properties

PACS: 61.80.-x, 78.20.-e, 81.15.Ef, 87.53.Bn

\section{Introduction}

Radiation processing is an expanding technology with numerous applications in, for example, health care products sterilization, sewage and hospital waste treatment, polymer modification, and food processing. The effectiveness of the irradiation process depends on the proper application of dose and its measurement. The required absorbed dose range would depend on both the product and the desired effect. Adequate dosimetry with proper statistical controls and documentation is the key factor of the quality control process, which is necessary to assure the products are properly treated. International Commission on Radiological Protection (ICRP) offers recommendations for the maximum permissible dose of gamma radiation to which people should be exposed, that is $1 \mathrm{mGy}$ per year for general public and 20-50 mGy per year for radiation workers.

Real-time radiation detectors become an essential part of emergency personnel who may have to respond to unknown accidents, incidents, or terrorist attacks, which could involve radioactive material. More and more ordinary citizens are interested in personal radiation protection as well. Reasons include lost sources, nuclear industrial accidents, nuclear or radiological ter- rorism, and the possibility of nuclear weapons being used in a war. People want to have the ability to measure it for themselves and they want to be notified when the radiation levels are increased.

To meet this demand, considerable research into new sensors is underway, including efforts to enhance the sensor performance through both the material properties and manufacturing technologies. The recent availability of various metal oxide materials in highsurface-area nanopowder form, as well as implementation of newly developed nanofabrication techniques, offer tremendous opportunities for various sensors manufacturers. New preparation technologies and optimized deposition process are essential to achieve better control of the material characteristics and consequently to improve the radiation sensor performance.

Accordingly, deep understanding of physical properties of the materials under the influence of radiation is vital for the effective design of devices for radiationsensing applications [1]. Mixing oxides in various proportions was found to control the radiation sensing properties of the semiconductor films in terms of their sensitivity to $\gamma$-radiation exposure and working dose region [2]. 


\section{Experimental procedure}

There are a wide variety of techniques for deposition of thin films. The examples are thermal evaporation (also known as vacuum vapour deposition), electron-beam evaporation, magnetron sputtering, chemical vapour deposition (CVD), and molecular beam epitaxy (MBE) [3-6]. Vacuum evaporation is a method used to deposit many types of materials in a highly evacuated chamber. It consists of vaporizing a solid material by heating it to sufficiently high temperatures and re-condensing it onto a cooler substrate to form a thin film. A large current is passing through a filament container (usually in the shape of a basket, boat or other crucible) with finite electrical resistance, thus heating the material. The evaporation temperature as well as inertness to alloying / chemical reaction with the evaporant dictate the choice of this filament material. Once the material is evaporated, its vapour undergoes collisions with the surrounding gas molecules inside the evaporation chamber. As a result, a fraction is scattered within a given distance during their transfer through the ambient gas. The mean free path for air at $298 \mathrm{~K}$ is approximately 45 and $4500 \mathrm{~cm}$ at pressures of $10^{-4}$ and $10^{-6}$ torr respectively. Therefore, pressures lower than $10^{-5}$ torr are necessary to ensure a straight-line path for most of the evaporated species and for substrate-to-source distance of approximately 10 to $50 \mathrm{~cm}$ in a vacuum chamber. The substrates with appropriate masks are placed above and at some distance from the material being evaporated. When the process is completed, the vacuum is released and the masks are removed from the substrates. This process leaves a thin, uniform film of the deposition material on all parts of the substrates exposed by the open portions of the mask.

The vacuum evaporation technique is most suitable for deposition of the materials that are difficult to evaporate in air. The method is clean and allows a better contact between the layer of deposited material and the surface upon which it has been deposited. In addition, because evaporation beams travel in straight lines, very precise patterns may be produced. In general, thermal vacuum deposition produces films with structural defects, such as grain boundaries or lattice imperfections [6]. The so-called minor defects, which are frequently observed in deposited films, include dislocation loops, stacking-fault tetrahedral, and small triangular defects; all of these are generally attributed to vacancy collapse [6]. Controlling the deposition conditions such as pressure, deposition rate, substrate temperature, and surface nature can alter the intensity of such defects. The settings for the evaporation procedure vary depending on the type of the material being deposited and desired film properties, such as thickness and conductivity.

An Edwards E306A vacuum thermal coating system was used for thin films' deposition in a number of our research experiments. The coating unit is equipped with a $550 \mathrm{~W}$ rotary pump and an E040 diffusion pump capable of achieving a vacuum of $5 \cdot 10^{-7}$ mbar. The coating unit consists of a vacuum chamber containing a fourposition turret source capable of holding four boats. A shutter is also incorporated, which shields the substrate from evaporants during the outgassing and baking. This system contains an Edwards FTM5 quartz crystal to monitor the rate of film deposition and to measure the film thickness. The quartz crystal was positioned directly above the evaporation source. The mass deposited on the quartz crystal during the evaporation alters its natural frequency of vibration. This frequency change was recorded on the meter of the film thickness monitor connected to the quartz crystal. Thus the monitor could record both the thickness and the rate of deposition corresponding to a particular frequency shift.

Initially, the evaporation chamber was lined with aluminium foil to avoid contamination of and by the surrounding walls. Clean brass masks with suitable apertures were used to deposit thin film structures in required patterns. Devices with cloverleaf geometry, planar-type and layered structures, as well as diodes were manufactured. The materials to be deposited were loaded into tungsten or molybdenum boat of various shapes and sizes, depending on the materials' properties. Then the materials are heated until the evaporation takes place. The settings for the evaporation procedure vary depending on the type of the material being deposited and desired film properties, such as thickness and conductivity.

Figure 1 shows the basic schematic of the overall vacuum evaporation system used for thin films' depositions.

In this work, two types of niobium oxide $\left(\mathrm{NbO}_{2}\right)$ thin films were deposited with the following parameters:

- Type $1 . \mathrm{NbO}_{2}$ powder was baked on a tungsten boat in a vacuum until outgassing was observed to cease, and a stable base chamber pressure of $10^{-6} \mathrm{mbar}$ was achieved. Glass substrates were initially heated to $300^{\circ} \mathrm{C}$ for 10 minutes and allowed to cool to $150{ }^{\circ} \mathrm{C}$. The $\mathrm{NbO}_{2}$ was then heated in the tungsten boat to achieve a deposition rate of $2.5 \mathrm{~nm} / \mathrm{s}$ at a vapour pressure of $8 \cdot 10^{-6}$ mbar. A film thickness of $98 \mathrm{~nm}$ was achieved. Afterwards, the films were annealed in vacuum at $300{ }^{\circ} \mathrm{C}$ for two hours. The 


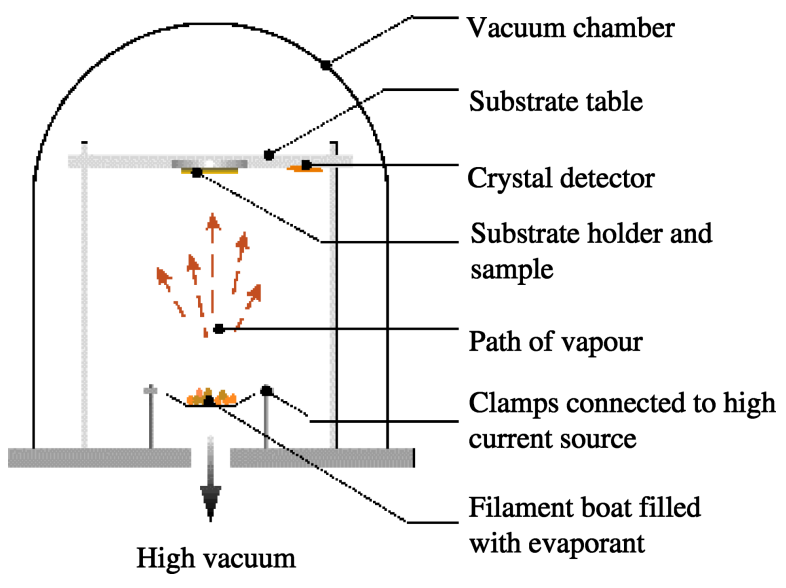

Fig. 1. Vacuum evaporation system

resultant films exhibited $n$-type behaviour and had resistance of approximately $4 \mathrm{M} \Omega$.

- Type 2. $\mathrm{NbO}_{2}$ powder was baked on a tungsten boat in a vacuum until outgassing was observed to cease, and a stable base chamber pressure of $10^{-6} \mathrm{mbar}$ was achieved. Glass substrates were held at room temperature. The $\mathrm{NbO}_{2}$ was heated in the tungsten boat to achieve a deposition rate of $4 \mathrm{~nm} / \mathrm{s}$ at a vapour pressure of $5 \cdot 10^{-6}$ mbar. A film thickness of $117 \mathrm{~nm}$ was achieved. These type 2 films also exhibited $n$-type behaviour, but the resistance was $400-500 \mathrm{k} \Omega$.

The effect of gamma radiation on glass substrate in the experimental dose range was neglected, as usually glasses can sustain higher radiation doses of up to 1 MGy without any change in their properties [7].

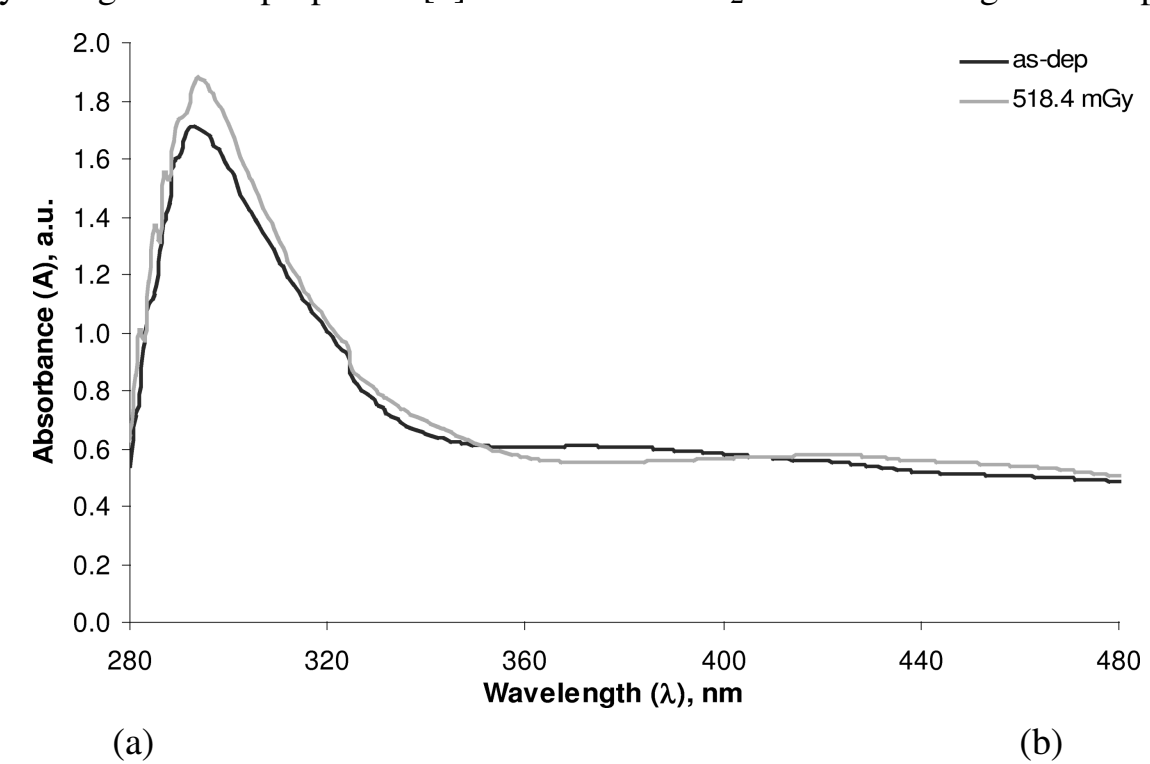

(a)

\section{Results and discussion}

To examine the sensitivity of the oxide films to gamma radiation, they were exposed to a disk-type ${ }^{137} \mathrm{Cs}$ radiation source with an activity of $370 \mathrm{kBq}$. The radioactive gamma-emitting element was encapsulated into a 2-mm thick high strength epoxy resin to shied any accompanying $\beta$-radiation. The source was held at a distance of $10 \mathrm{~mm}$ from the surface of the film at an angle of incidence of $0^{\circ}$. The optical properties of $\mathrm{NbO}_{2}$ thin films were explored using CARY $1 \mathrm{E}$ UV-Visible Spectrophotometer. Figure 2 illustrates the change in the optical absorption spectra of $\mathrm{NbO}_{2}$ (type 1) films under the influence of $\gamma$-dose of $518.4 \mathrm{mGy}$. An increase in the absorbance values was recorded at wavelengths from 280 to $350 \mathrm{~nm}$. Figure 3 depicts a change in the optical absorption spectra of type $2 \mathrm{NbO}_{2}$ films as a result of $389 \mathrm{mGy} \gamma$-dose. Moreover, type 2 films were more sensitive to lower dose of $389 \mathrm{mGy}$, notwithstanding the fact that these films were a bit thicker than counterpart type 1 films. Accordingly, the composition of the films alone also plays profound role in their gamma radiation sensing ability. It could be explained by the earlier demonstrated fact that in the composition range from $\mathrm{NbO}_{2}$ to $\mathrm{Nb}_{2} \mathrm{O}_{5}$ instable phases $\mathrm{Nb}_{12} \mathrm{O}_{29}$, $\mathrm{Nb}_{22} \mathrm{O}_{54}, \mathrm{Nb}_{25} \mathrm{O}_{62}$, and so forth exist [8].

These findings are in line with the results reported earlier for $\mathrm{TeO}_{2}$ thin films, since the optical properties of thermally deposited $\mathrm{TeO}_{2}$ thin films having a thickness of $50 \mathrm{~nm}$ also have shown a high sensitivity to gamma radiation $[9,10]$. Typical plots of the absorption spectra for as-deposited and $\gamma$-irradiated thin films of $\mathrm{TeO}_{2}$ are shown in Fig. 4. The optical band gap value

Fig. 2. Change in the optical absorption spectra of $\mathrm{NbO}_{2}$ (type 1) films under the influence of $\gamma$-dose of $518.4 \mathrm{mGy}$. 


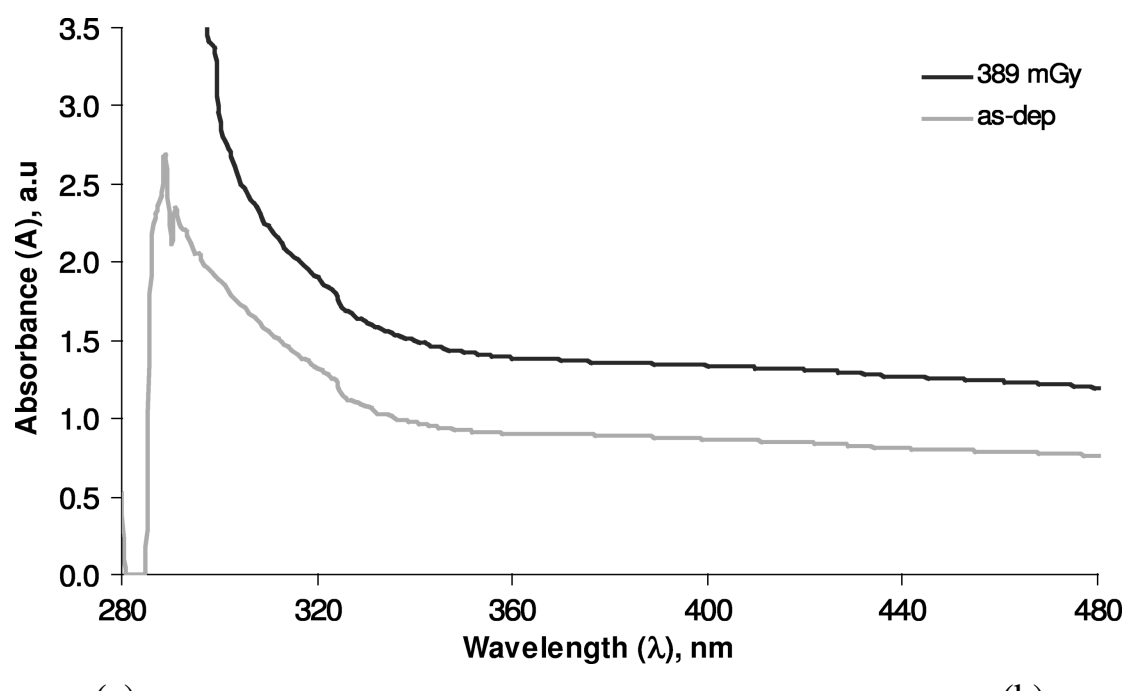

(a)

(b)

Fig. 3. Change in the optical absorption spectra of $\mathrm{NbO}_{2}$ (type 2) films under the influence of $\gamma$-dose of $389 \mathrm{mGy}$.

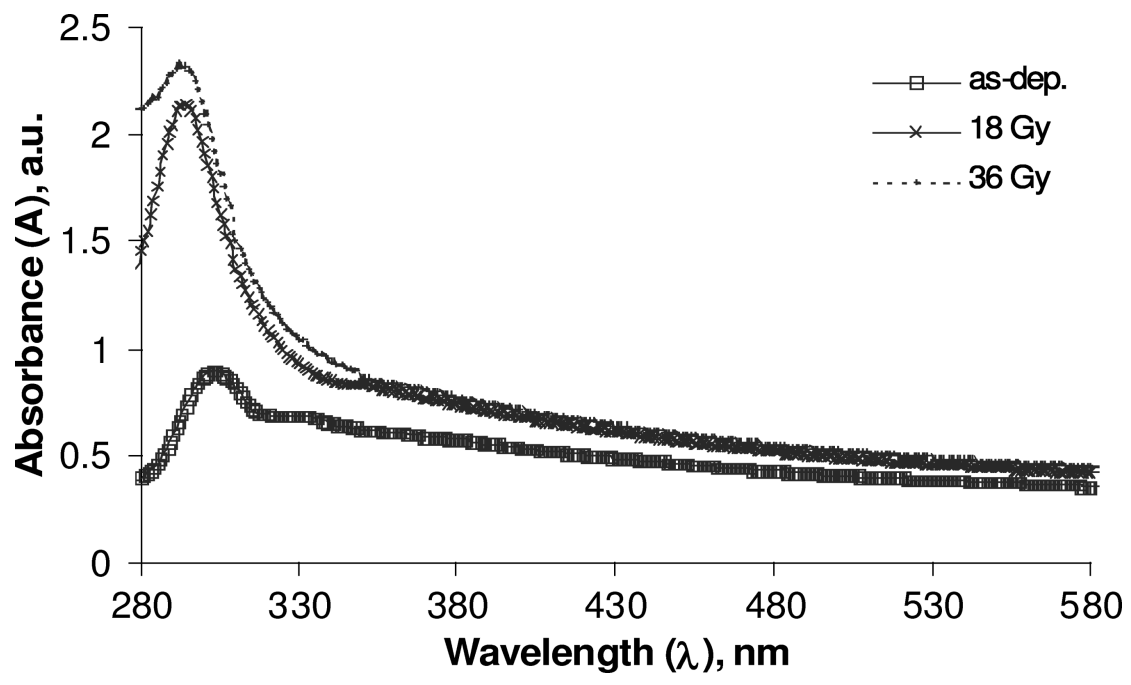

Fig. 4. Absorption spectra for as-deposited and irradiated $\mathrm{TeO}_{2}$ thin films, () 2003 IEEE [10].

decreased from 3.75 to $3.45 \mathrm{eV}$ with the increase in radiation dose up to $36 \mathrm{~Gy}$. The values of the optical band gap $\left(E_{\text {opt }}\right)$ for as-deposited and $\gamma$-irradiated specimens were estimated using the Mott and Davis model for the direct allowed transition [11]. The variation in the optical energy gap with irradiation can be explained using the density-of-state model. It is known that $E_{\text {opt }}$ decreases with the increase in the degree of disorder of the amorphous phase [12]. At this stage one may expect a band tail to be, probably, created due to irradiation. The decrease in $E_{\text {opt }}$ leads to a shift in the band tail $\Delta E$ towards the higher energy region and hence the calculated value of $\Delta E$ is expected to increase as the radiation dose is increased. Generally, wide band gap compound semiconductors, in particular glassy materials, are of interest for room-temperature ionizing radiation detec- tion. However, pure amorphous materials are preferred over typical glasses. In turn, pure crystalline materials are preferred over the pure amorphous because of their greater number of states and their structural characteristics, such as greater susceptibility to permeation [13].

Detection of radiation was based on the fact that electrical, optical, and structural properties of the materials undergo changes under the influence of gamma radiation. The influence of radiation depends on both the dose and the parameters of the films including their thickness: the degradation is more severe for the higher dose and the thinner films. Values of radiation damage in the samples were estimated from changes in their current-voltage characteristics and the optical absorption spectra, which were recorded after each exposure procedure. 
Radiation sensors have dose response characteristics with certain level of sensitivity and working dose range, conditioned by particular sensing material properties and the device structure including film thickness [1418]. Therefore, a combination of a number of sensors with different response parameters into sensor arrays would enhance the overall performance of the radiation detection system, including broadening the measured dose range and lowering a minimum detectable dose.

\section{Conclusions}

$\mathrm{NbO}_{2}$ thermally evaporated thin films were explored as candidates for cost-effective personal radiation sensors. The properties of these films were highly affected by the influence of radiation. The degree of changes caused in their optical properties was correlated with the level of gamma dose and also depend on the materials' properties and parameters of the films. Thus, the sensitivity range of the metal oxides' thin film sensors can be tailored for a particular application.

\section{References}

[1] O. Korostynska, K. Arshak, D. Morris, E. Jafer, and A. Arshak, Wireless real time compact radiation detector based on $\mathrm{Bi}_{2} \mathrm{O}_{3} / \mathrm{Nb}_{2} \mathrm{O}_{5}$ thick film capacitors, Sensors Actuators Phys. 142, 28-33 (2008).

[2] K. Arshak and O. Korostynska, Advanced Materials and Techniques for Radiation Dosimetry (Artech House, Boston, 2006).

[3] R.F. Bunshah, Handbook of Deposition Technologies for Films and Coatings - Science, Technology and Applications (William Andrew Publishing/Noyes, Park Ridge, 1994).

[4] B.N. Chapman, Glow Discharge Processes: Sputtering and Plasma Etching (Wiley, New York, 1980).

[5] R.V. Stuart, Vacuum Technology, Thin Films, and Sputtering: An Introduction (Academic Press, New York, 1983).
[6] L.I. Maissel and R. Glang, Handbook of Thin Film Technology (McGraw-Hill Book Company, New York, 1983).

[7] K. Arshak, O. Korostynska, and G. Hickey, Gamma radiation and ozone sensing properties of $\mathrm{In}_{2} \mathrm{O}_{3}: \mathrm{ZnO}: \mathrm{SnO}_{2}$ thin films, Proc. SPIE 6589, 658916 (2007).

[8] S. Burachas, M. Ippolitov, V. Manko, V. Lomonosov, S. Nikulin, A. Vasiliev, Yu. Savelev, A. Apanasenko, and G. Tamulaitis, Defect clusters of variable composition as an origin of coloration of oxide crystals under thermal treatment and irradiation, Radiat. Meas. 42, 561-564 (2007).

[9] K. Arshak and O. Korostynska, Effect of gamma radiation onto the properties of $\mathrm{TeO}_{2}$ thin films, Microelectron. Internat. 19(3), 30-34 (2002).

[10] K. Arshak and O. Korostynska, Gamma radiationinduced changes in the electrical and optical properties of tellurium dioxide thin films, IEEE Sensors J. 3, 717721 (2003).

[11] N.F. Mott and E.A. Davis, Electronic Process in Noncrystalline Materials (Clarendon Press, Oxford, UK, 1979).

[12] M.V. Kurik, Urbach rule, Phys. Status Solidi A 8, 9-45 (1971).

[13] E. Colby, G. Lum, T. Plettner, and J. Spencer, Gamma radiation studies on optical materials, IEEE Trans. Nucl. Sci. 49, 2857-2867 (2002).

[14] K. Arshak and O. Korostynska, Thick film oxide diode structures for personal dosimetry application, Sensors Actuators Phys. 113, 319-323 (2004).

[15] K.I. Arshak, J. Molloy, O. Korostynska, and J. Harris, $\mathrm{MnO} / \mathrm{TeO}_{2}$ thin films as optical gamma radiation sensors, in: Sensors, 2004, vol. 3, Proc. IEEE (2004), pp. $1285-1288$.

[16] K. Arshak and O. Korostynska, Influence of gamma radiation on the electrical properties of $\mathrm{MnO}$ and $\mathrm{MnO} / \mathrm{TeO}_{2}$ thin films, Ann. Phys. 13, 87-89 (2004).

[17] K. Arshak and O. Korostynska, Thin- and thick-film real-time gamma radiation detectors, IEEE Sensors J. 5, 574-580 (2005).

[18] K. Arshak and O. Korostynska, Gamma radiation sensors arrays based on metal oxide thick films, Sensor Rev. 26, 70-75 (2006). 


\title{
EKONOMIŠKA ASMENINĖ SPINDULIUOTĖS DOZIMETRIJA
}

\author{
O. Korostynska, K. Arshak, J. Harris
}

Limeriko universitetas, Limerikas, Airija

\section{Santrauka}

Norint sukurti efektyvius dozimetrinius prietaisus, būtina giliai suprasti fizikines medžiagų, patiriančiu spinduliuotès poveiki, savybes. Jonizuojančios spinduliuotès detekcija remiasi tuo, kad dèl jos įtakos kinta medžiagų elektrinès ir optinès savybės. Manoma, kad spinduliuotė sukelia sandaros defektus (vadinamus spalvos centrais arba deguonies vakansijomis oksiduose), kurių tankis kinta priklausomai nuo ekspozicijos trukmès.

Laikoma, kad plonujų sluoksnių technologija yra ekonomiška alternatyva kuriant pačius ivvairiausius jutiklius. Ji ypač patraukli naudojant metalų oksidų sluoksnius, kuriụ lydymosi temperatūra yra žemesnė nei $2000^{\circ} \mathrm{C}$, nes taip galima pagaminti ištisą spektrą mišrios sandaros sluoksnių. Spinduliuotès įtaka tokiems sluoksniams priklauso ir nuo dozès, ir nuo sluoksnių parametrų, pavyzdžiui, storio: pažeidimai didesni, kai dozè didesnè ir sluoksnis plonesnis.

Aptariamos galimybès aptikti gama spinduliuotę, naudojant termiškai garinamus $\mathrm{NbO}_{2}$ plonus sluoksnius. Sluoksniai užgarinti skirtingu padengimo greičiu, esant skirtingam slègiui. Eksperimentiškai patvirtinta, kad sluoksnių gamybos parametrai turi įtakos gama spinduliuotès aptikimo jautriui. 